\title{
More Than Bling: Inscribed Jewellery Between Social Distinction, Amatory Gift-Giving, and Spiritual Practice
}

One of the most fascinating aspects of inscribed jewellery is how far it can cross time and space, and how it can connect different cultural practices and fields of knowledge. It is often durable, and attractive or valuable enough to be transported and preserved. For example, a ring with a Kufic inscription interpreted as il-la-lah ("For/to Allah") found its way to ninth-century Sweden, and survived into the twenty-first century. ${ }^{1}$ The ring began as a religious ornament, was traded, maybe given as a gift, worn as an amulet, buried with a woman, unearthed and misinterpreted by nineteenth-century archaeologists, and finally analysed with an electron microscope and turned from Arabic silver into a virtual 3D model. The ring has thus been part of religious devotional customs, trade, personal ornamentation, burial cult, and archaeological practices.

Medieval literature expresses great interest in setting up such constellations around inscribed jewellery, which often refuse strong categorisation and instead entwine different phenomena, practices and fields. ${ }^{2}$ This article interprets such examples, mostly from Middle High German, Old and Middle English texts. As I will show, jewellery functions primarily to create relationships between people-it can symbolize, initiate, affect, and bear witness to them. Inscriptions can increase such constellations' complexity: they can intensify or personalise gifts, add layers of ambiguity, and even stress the way objects interact with people as nonhuman actors.

\section{Two Observations on Methodology}

Jewellery has existed from prehistoric to postmodern times. The similarities between archaeological finds and modern objects and practices raise two methodological questions. $^{3}$

First, jewellery challenges us to think about phenomena from other cultures and times, whose deceptive familiarity may obscure their meaning. We relate to an Anglo-Saxon ring engraved ðancas ("thank you”) or a seventeenth-century ring

1 See Wärmländer et al. 2015; on rings in general, see Robinson 2008; Scarisbrick 1993; Ward 1981; Evans 1931.

2 On luxury as a complex category connecting different discourses and allowing medieval literature to mark difference, see Eming et al. 2015.

3 See Smith 1908, xxxvii-xlvii; Rieger 2016.

Ә Open Access. (c) 2019 Christoph Witt, published by De Gruyter. (c) BY-NC-ND This work is licensed under the Creative Commons Attribution-NonCommercial-NoDerivatives 4.0 License. 
inscribed "Y.AM.YOVRS.FOR.EVER". ${ }^{4}$ But what about the Wheatley Hill Ring's enigmatic declaration "I am called a ring"? 5 Archaeological approaches therefore work to understand objects within their cultural context, especially when analysing inscribed items. But if we are to always historicise, then on which context do we focus? Do we focus on an object's creation, or on the many other moments when it might have been utilised $?^{6}$ Time can change even what items are considered jewellery at all. This article therefore requires some definition of “jewellery", and attends both to an object's original meaning and function and to its shifting contexts.

Secondly, an analysis of inscriptions in medieval literature must consider what historical reality actually can tell us about literary texts. Because literature is rooted in a specific material culture, the more recent research in Material Studies has increased interest in interdisciplinary work. It has reinvigorated debates about how to best draw on historical contexts without either treating literary descriptions of fictional objects like imprecise archaeological reports (whose ambiguities or blank spaces need positivistic amendments), or turning historical context into the last court of appeal about what literature can mean, since literature is perfectly capable of fictionalising historical reality for its own means. ${ }^{7}$

\section{A Definition of Jewellery}

Especially courtly literature revels in describing lavishly adorned objects-arms, goblets, bridles, even perfume dispensers. ${ }^{8}$ Clearly, not all that glitters is jewellery. But what about jewels sewn on garments? ${ }^{9}$ What do we make of ornaments that resemble other things, such as bracteat medals imitating Roman coins, ${ }^{10}$ or objects that resemble ornaments, such as pilgrims' medals? ${ }^{11}$ Objects might have several functions or change purpose over time.

This article shall use "jewellery" to denote beautiful artefacts designed to be displayed visibly on the body. Part of the value of jewellery derives from craftsmanship, part from its precious substance. A piece of jewellery can consist of several materials,

4 See Okasha 1971, 137; British Museum, AF.1404.

5 ring ic hatt, see Finger-ring (British Museum 1995,0902.1); see Page 1999, 169.

6 See Hilgert 2010, 97f., 108-114; compare to Harris/Overbey 2014, 134f., 137-143.

7 See Ott/Focken 2016; Bintley 2012; Johnston 2017, 225-234; Johnston 2008, 177-180; Felski 2011, 578-588.

8 For example, see Wigalois (thirteenth century), 8888-8890; 10359-1079. All references to Wigalois are to Wirnt von Grafenberg (2014).

9 See, for example, Wigalois, 8906f. and Diu Crône (c. 1230), 7704-7737. All references to Diu Crône are to Heinrich von dem Türlin (2012).

10 See Page 1999, 183-185, McKinnell/Simek/Düwel 2004, 69-84; MacLeod/Mees 2006, 85-87.

11 See Smith 1908, $108 \mathrm{f}$. 
such as gemstones and metal, allowing for complex symbolism. For example, gold often symbolises excellence and inner values, while gems point to wisdom or magic, and are often understood allegorically. ${ }^{12}$ This composite character allows jewellery to appear in diverse contexts in literature. Finally, this article assumes that jewellery has an aesthetic purpose extending beyond any functional demands it might serve-a pin does not have to be set with diamonds to perform its task, for instance. ${ }^{13}$

\section{Medieval Functions of Inscribed Jewellery Beyond the Aesthetical}

The definition of jewellery as a personal, precious ornament worn primarily for its beauty does not mean jewellery was only displayed for its aesthetic appeal. An important source on medieval jewellery, Theophilus Presbyter's Schedula Diversarum Artiiim (twelfth century) was transmitted together with treatises on the meaning of colours, medicine, alchemy and astronomy. ${ }^{14}$ This range reminds us that medieval jewellery does not have to follow modern categories: surviving amulets, rings, and pendants inscribed with prayers, charms, the names of the Three Kings or the Aramaic magic formula THEBAL, entangle what modernity would divide into magic, religion, astrology and medicine. ${ }^{15}$ Even medieval attempts to separate magic and religion betray the phenomena's proximity; prohibitions such as Thomas Aquinas' rules (Summa Theologiae, ii. 2b, questio 96) against inscribing incomprehensible words or invocations of powers other than God's do not seem to have governed most surviving pieces. ${ }^{16}$ From a synchronic point of view, an artefact could signify differently to different people, or simultaneously serve several purposes. ${ }^{17}$

A diachronic perspective on inscribed jewellery shows that it could also defy religious, cultural, regional, or temporal divisions. Byzantine influence on medieval ornaments challenges the binary of East and West. ${ }^{18}$ Anglo-Saxon metalwork used traditional engravings of animals and zoomorphs to invite multivalence within

12 See Horn 1987, 1357f.; Engle 1981, 1003-1007.

13 See also the similar definitions in Smith 1908, xxxiii; Evans 1976, 13.

14 See Brepohl 1999; Speer 2014, xi-xiv, xxii-xxv.

15 On gems and inscribed jewellery entangling magic, religion and medicine, see Evans 1976, 9-24, 29-32, 48-54, 95-114; MacLead/Mees 2006, 188, 190. On religious and magical inscriptions, see Smith 1908, 132, 150-152; Krabath 2016, 254f.; Evans 1976, 122-132. For an individual example, see Finger-ring (British Museum OA.10262).

16 See Evans 1976, 132.

17 For example, the approximately 20 inscribed rings surviving from Anglo-Saxon times seem to have served a variety of purposes. See Okasha 2003, 29-31, 38, $40 \mathrm{f}$.

18 See Smith 1908, 33-36. 
Christian Mediterranean contexts. ${ }^{19}$ Modern scholarship often associated runes with (especially pagan) magic, but few runic inscriptions seem to have served exclusively magical purposes, and many go beyond a simple dichotomy of pagan and Christian. ${ }^{20}$ Incomprehensible inscriptions might not be occult but rather seeking to benefit from the prestige associated with literacy by using writing as a decorative element. ${ }^{21}$ Latin, Hebrew, or vernacular pagan and Christian charms and prayers, written in Roman or Runic script, or both, appeared on rings or amulets that sometimes even were reworked from ancient gemstone talismans originally used as seals. ${ }^{22}$ The medieval lapidaries that attributed medical and magical powers to them were influenced so fundamentally by Antiquity that the Renaissance left this field of knowledge unchanged. ${ }^{23}$

Jewellery's capacity of entangling different practices, languages, times and cultures can therefore also produce fascinating constellations in literature. In order to interpret inscribed jewellery in medieval literature, this article takes its functions beyond ornamentation as departing points. Aesthetical aspects remain central, but not in the sense of an opposition of pretty versus practical or meaningful objects. Medieval objects often were crafted in ways that drew attention to and involved their material qualities to underline specific points or induce certain reactions-though we should not presuppose a single concept of materiality for the Middle Ages. ${ }^{24}$ Accordingly, medieval jewellery should not be thought of as mostly pretty, useless and precious, and occasionally coming with an additional, actual function. Rather, its beauty and preciousness often is what allows jewellery to serve its purpose.

Inscribed jewellery occurs much less often in medieval literature than could be expected given the prominence of both inscriptions and jewellery in literature, along with the archaeological evidence showing that inscribed jewellery would have been conceivable for authors. But the leading question here will not be why inscribed jewellery occurs comparably rarely, but what inscriptions contribute to the respective functions of jewellery.

19 See Herman 2017, 49, 55f., $59 \mathrm{f}$.

20 See especially Page 1999, 12-14, 106-114. See also McKinnel/Simek/Düwel 2004, 31f.; Page 1964, $74 \mathrm{f}$.

21 See Webster 1991, 95 f.

22 See Evans 1976, 14; on runic Latin and Hebrew charms see MacLeod/Mees 2006, 16-18; McKinnell/ Simek/Düwel 2004, 147-154; on Christian inscriptions and prayers in runes, see MacLeod/Mees 2006, 184-187, 202f, 208-210; McKinnell/Simek/Düwel 2004, 172f., 181-186; on the relationship between runic and Roman letters in general, see Page 1999, 212-225.

23 See Evans 1976, 140, 13-94, 170, 184, 72f, 156. On medieval lapidaries, see Cohen 2015, esp. 211-222; Murphy 2006, 42-68.

24 See Robertson 2010, 102-107; Bynum 2011, 24, 34, 37f., 58-70, 105, 231. 


\subsection{Showing Political Power and Social Distinction}

The most notable purpose of jewellery is to mark social distinction. ${ }^{25}$ Literary texts reflect this as well. Characters often wear jewellery in situations of symbolic representation, such as rulers making public appearances. Inscriptions can increase the impact of jewellery, independently of their semantic content, simply because writing enjoyed special prestige. ${ }^{26}$ Therefore, wearing jewellery is more than merely decorative. It marks actual, tangible power, and membership in a cultural elite. Because especially chivalric culture constantly re-affirms itself and communicates through such visible, material signs, it is crucial to consider how openly a piece of jewellery is being displayed, by whom, and for whom to see, to understand its significance for a specific text.

Crowns and wreathes are the most ostentatiously worn form of jewellery. Crowns and diadems are central ruling insignia. Wreathes tend to occur in the contexts of challenge and victory, and can mark seasons, periods, or ceremonies. ${ }^{27}$ Their material is often significant-may wreathes consist of spring flowers, ${ }^{28}$ and can incorporate symbolically charged plants, such as roses, laurel, or straw. ${ }^{29}$ Medieval crowns probably developed from such ancient wreathes. Golden wreathes (as in Wigalois, 851855) testify to the remaining connection between crowns and wreathes. Both appear in similar contexts in literature, as marks of class privilege or excellence. Wreathes are sometimes said to "crown" characters, and the terms sometimes even occur interchangeably.

Few surviving crowns bear inscriptions. There are spectacular exceptions, such as the seventh-century votive crowns of King Reccesuinth and King Swintila, with letters hanging from their rims naming the royal donors. ${ }^{30}$ They were probably suspended in consecrated buildings, articulating ownership and standing in for the absent kings. This echoes in the metonymical expression of "the crown" (as in " $x$ belongs to the Crown") for kingship as such. Such expressions can take on a more literal meaning, especially considering Latour's concept of material objects as actants, ${ }^{31}$ or the idea of a king's two bodies: crowns can transform someone into a king, symbolizing and creating power. Such public markers become particularly significant when someone's social position is re-negotiated-at coronations, baptisms, or weddings.

25 See, for example, Gaimster 2011, 874-876.

26 This might explain why texts often do not quote inscriptions. See Lieb 2015, 11-12.

27 See Fährmann 1996, 491; Smith 1908, xxxix, 35, 105-107.

28 See, for example, B224 "Von dem mayen krantz", in: Liederbuch der Clara Hätzlerin 1840, 234-238 (260-287).

29 See, for example, "Von dem mayen krantz", 146-149, 338-343; and "Vonn einem stroyn krenntzleyn”, in: Liederbuch der Clara Hätzlerin 1840, 187-191 (89-124).

30 See López 1994, 53-56; Eger 2004, 450-456, Plate 1 and 29, Smith 1908, 53-55.

31 See Latour 2005, 70-82. 
In chapter 1 of the Gesta Romanorum, an early fourteenth-century medieval collection of exempla, inscribed jewellery mirrors the network that constitutes someone's social identity in such a moment. A knight returns Emperor Pompeius's daughter after duelling her seducer. A sage reconciles her with her father, and she receives several inscribed presents, including a tunic embroidered with words of forgiveness. A king gives her a golden wreath or crown inscribed, "I give you your dignity" (Ex me tua dignitas), while his son gives her a ring inscribed, "Come to me, do not be scared. I am your brother" (Accede ad me, ne timeas! frater tuus sum), and another saying "You are noble, do not scorn your nobility" (Nobilis es, nobilitatem tuam ne contempnas), the knight gives her a ring engraved "I loved you, learn how to love, too" (Dilexi te, disce diligere), the sage gives her a ring inscribed "What did I do? How much? Why?" (Quid feci? quantum? quare?), and her new husband gives her a sigil that says "Now you are conjoined with me, do not err" (Jam conjuncta es, amplius noli errare). ${ }^{32}$ These gifts publicly restore the princess's royal status, and show her new legal authority. Their significance relies on the relationships between receiver and giver, and the situation of the present being made. Some of the inscriptions phrased in the first person can even be read as blending the voices of gift, giver and recipient into one. The crown, for example, symbolises the royal dignity the king is granting the princess, but it is literally the crown, as an object, that bestows it upon her.

Rulers bearing the nature of their power written on their heads already occur in the Book of Revelations, and inscriptions on crowns or diadems occasionally work similarly. ${ }^{33}$ But crowns are such strong symbols themselves that the inscription on Alexander's crown in Der Große Alexander (late fourteenth century),

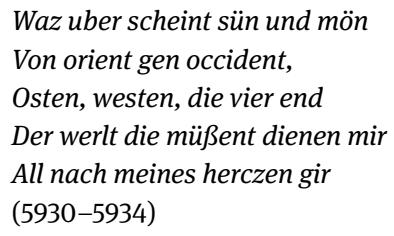

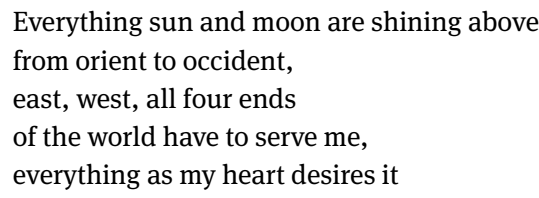

can be read as announcing Alexander's premise, the desire to conquer the entire world, but might also be understood as the crown's own words, thus turning Alexander into a mere servant to power itself. In Seifrit's Alexander (c.1352), Alexander is even contrasted with another source of authority: the Jewish High Priest's headdress is topped with a gemstone engraved with God's name (1835-1848). ${ }^{34}$

Jewellery can also exhibit allegiance or position, such as episcopal rings or livery collars like the Collar of Esses, consisting of 28 golden "S", still a part of the Mayor of

32 See Oesterley 1872, 273-275.

33 See, for example, Revelations 13:1, 19:12.

34 Compare to Exodus 28 and 39. 
London's attire. ${ }^{35}$ Rings especially could be worn either openly or more discreetly. ${ }^{36}$ However, the degree of overtness also depends on how an object is distributed. For example, in Wigalois, a messenger publicly presents Wigalois and his father Gawein with a ring his mother Florie sent them before dying of grief, inscribed,

owê, geselle und ouch mîn kint! von iu mîn varwe ist worden blint, mîn rôtez golt gar überzint.

(11365-11367)
Woe, my confident, and my child, too because of you my colours faded and my red gold was coated with tin.

This genealogically charged example blends together the relationships between husband, mother and son. The inscription appears as Florie's own words, yet its metaphors emphasise that its speaker consists of metal, not flesh and blood. Applying the image of a lover's colours fading from grief to jewellery, the inscription offers two insights. Tin as coating for the more precious gold transforms jewellery into an image for sincerity, thus stressing Florie's virtues. Furthermore, jewellery's usual resistance to the decay described here stresses the enormity of Florie's suffering. It might even recall the ruby she wore when first meeting Gawain, whose colour had the power to obliterate any worries (792-800). The effect is that as the family is symbolically reunited at the story's conclusion, Florie's husband and son mourn her pain and praise her virtue.

The connection between social identity and inscribed rings probably was influenced by the Greco-Roman practice of carrying gemstone seals on rings, consisting mostly of images, sometimes with captions. ${ }^{37}$ Later, carvings in the rings' metal increasingly took over that function. ${ }^{38}$ The way such rings could be used to transfer or share authority exemplifies two more core principles for inscribed jewellery in literature. One: often, jewellery is given to (or taken by) someone, and this co-determines its significance. We must ask who gave what kind of object to whom, and under which circumstances. The inscription on Florie's ring requires the information that she sent it from her deathbed to the husband who left her, and the son who went in search of him. Secondly, if jewellery is meant to be given away, it makes sense to engrave not its present owner's, but the original giver's name. ${ }^{39}$ Inscriptions are not simple name tags or proofs of property-medieval societies were mostly illiterate, and individual pieces were recognisable enough. ${ }^{40}$ Instead, such inscriptions can express a special

35 On Office rings, see Smith 1908, 147-149, on the Collar of Esses, see Smith 1908, 116f.

36 Rings were also worn as amulets. See Page 1999, $112 \mathrm{f}$.

37 See Smith 1908, 18, 31f., $153 \mathrm{f}$.

38 See Smith 1908, 53. Engraved gemstones remained popular, and apparently Roman gemstone seals were sought after and re-used exclusively as jewellery, see Platz-Horster 2011, 225-227.

39 See Okasha 2003, 37-41. See also Okasha 1995. For a practical example of the challenges posed by a ring's inscription of two names, see Okasha 1973, 169-170.

40 See Okasha 2003, $40 \mathrm{f}$. 
identification between a person and an object, which turns it into a powerful form of articulating a personal connection. ${ }^{41}$ Inscriptions, then, do not represent the identity of an object's owner, but a relationship to its giver. A royal donor's inscription would significantly increase an item's value. Such gifts also showcase a ruler's influence-to pick up the idea of a name tag again, a ruler puts his or her mark on someone else. The giver's name and rank would be the simplest inscription, but other surviving examples relate to the gift's story, occasion, or origin, as illustrated by the ninth-century Manchester Ring inscribed, "Ædred owns me, Eanred wrought me”. ${ }^{42}$ Having the ring itself speak out imagines it as an independent materialisation of the relationship.

Such examples demonstrate that publicly worn jewellery can show social standing, expressing the relationships an item is connected with, and that an inscription therefore should be read with regard to these networks. Does it, for example, intensify and personalise a gift, specify a relationship, grant authority, or allude to particular moments of a shared past? This is another core principle for almost every piece of inscribed jewellery in literature.

\subsection{Creating Political Power}

In the act of being given or taken, jewellery does not just present social distinction but can also directly create political power. The aristocratic warrior society many premodern and medieval texts depict engages in ritual and symbolic gift-exchange (of weapons, food, jewellery, or service) as a social challenge between giver and receiver that establishes rulers, and negotiates alliances and hierarchies. ${ }^{43}$ Variations of "ring-giver" are common Old English metaphors for a lord whose retainers repay his gifts with fighting services. ${ }^{44}$ Wearing such jewellery displays a warrior's esteem. ${ }^{45}$ It also allows someone to create their own alliances through gift-exchange, to forge

41 See Owen 2011, 96.

42 For examples of rings inscribed with names and ranks, see the Æthelswith Ring (British Museum AF.458) and Æthelwulf Ring (British Museum 1829,1114.1). For an inscription referring to the item's history, see, for example, the Sigerie Ring, inscribed SIGERUE HED MEA GEVVIRCAN ("Sigerie ordered me to be made"), Okasha 1971, 136f., or the seventh-century Hardford Farm Brooch's runic inscription, luda giboetæsigilæ ("Luda mended the brooch") see Page 1999, 166. An alternative reading, "may Luda make amends by means of the brooch", would instead focus on the gift's occasion. See Bammesberger 2003. On the Manchester Ring, inscribed + AEDRED MEC AH EANRED MEC AGROF (Finger-ring, British Museum SLRings.64), see Page 1999, 161f., 12f.; Okasha 1995.

43 For example, see Beowulf, 64-81; Roman d'Eneas, 3127-3142, 3216-3254; Heinrich von Veldeke 1997, 113.15-116.4-7. On gift exchange theory, see Mauss 2002; Levi-Strauss 1969; For an application to gift exchange in medieval literature (specifically Beowulf), see Johnston 2008, 69-90.

44 See The Seafarer, 83; Beowulf, 20-24, 1102, 1602, 2490-2493; The Wanderer, 34-36; Juliana, 22, Maxims II, 14f., $28 \mathrm{f}$.

45 See, for example, The Fight at Finnsburgh, 13 and Beowulf, 1025-1057, 2142-2199. 
connections of loyalty, for instance. ${ }^{46}$ Here, too, the way such objects change owners crucially influences their significance. This is especially evident when gifts of friendship are stolen as war trophies, thus becoming tokens of military triumph to one party, and incitements of revenge to the other. ${ }^{47}$

We must note that inscribed jewellery hardly occurs in gift-exchange. For example, it is effectively absent from Old English texts. ${ }^{48}$ This might be a question of literary tradition, or of a desire to construct a heroic, illiterate past. ${ }^{49}$ Inscriptions might also distinguish an object so much as to inhibit its continuous circulation as a gift. Their close association with particular situational aspects might render the object illegible if given away. Two chapters from the Gesta Romanorum mention inscriptions that can only be understood correctly within their situational ties: In chapter 8, a nobleman is executed because he relates a sacrosanct statue's inscription to himself, taking a ring it appears to offer (282-284). In chapter 265 (app.69), a Saracen realises a statue's inscribed crown actually reveals the location of a treasure buried where its shadow darkens the ground on a specific day (667). Such material and contextual aspects of writing will inevitably transform an original meaning if the object were transferred as a gift. Especially inscriptions concerning specific relationships between donor and recipient might become obscure or alter their significance. ${ }^{50}$ This might be the reason why inscribed jewellery does occur in one particular constellation (one similar to political gift-exchange) where the point is that it must not be passed on: as a gift between lovers.

\subsection{Amatory Relationships}

It is a central function of jewellery to serve as a gift of love. ${ }^{51}$ Archaeological evidence ranges from sixth-century runic brooches to fifteenth-century rings inscribed with sophisticated Norman-French love verses or grammatical jokes. ${ }^{52}$ Giving a ring

46 See Heinrich von Veldeke 1997, 170.30-172.2; Beowulf, 1215-1231. See also Johnston 2008, 66-77. The active role of female participants in gift-exchange has long been neglected. See Gaimster 2011, $876-881$.

47 Beowulf, 1192-1213, 2032-2056; compare Heinrich von Veldeke 1997, 207.9-36, 331.5-38, and Roman d'Eneas, 5763-5774, 9793-9814, to Vergil's Aeneis, X.495-505, XII.938-949.

48 See, for example, Okasha 2003, 37, 40-41; Hinton 1975, $177 \mathrm{f}$.

49 See Johnston 2009, 144-147; Johnston 2016a, 213-214.

50 This observation on inscriptions might suggest that especially in non-typographical societies writing might be generally considered a material phenomenon comprehensible because of situational ties, in contrast to more modern, immaterial concepts of writing as transmitting information transparently from one situation to another. See Bode 1994, 148-149, on this observation concerning Shelley's “Ozymandias”. See also Fleming 2001, 19-27.

51 See, for instance, Egidi 2012.

52 The British Museum holds magnificent specimens, such as a fourteenth-century gold ring en- 
at a betrothal probably originated in Rome and developed into ring exchange in the thirteenth century. ${ }^{53}$ Inscribed rings were already popular presents in early Christian Byzantium. ${ }^{54}$ Whereas fourteenth-century Jewish wedding rings inscribed with Mazel Tow probably belonged to the community and were borrowed by couples just for the wedding ceremony, thus making them symbolic ritual objects, not personalised gifts. ${ }^{55}$ Posy rings increasingly appear as engagement gifts from the sixteenth century onwards..$^{56}$

Literature, too, contains countless examples of jewelled belts or rings given by lovers, or for love. ${ }^{57}$ Similar to political gifts, such presents also often express intimacy by inscribing the giver's name on the gift. Jewellery can be a public or more secretive declaration of love. Inscribed wreathes, for instance, are important in courtship. A particularly enigmatic example occurs in the poem Von ainem Crantz (at latest fourteenth century): A party of men receives wreathes with ostrich feathers, each bearing its recipient's initials-a convivial challenge to guess the presents' donors (643-645, 1-9). As a different kind of challenge, potentially less playful but more programmatic and explicitly meant to bind publicly, wreathes also occur within the courtly tradition of ladies adorning their knights. In Der Jüngere Titurel (no later than c. 1300), Sigune weaves Tschionatulander an inscribed wreath for his helmet that publicly proclaims she gave it to him as the crown of her maidenhood $(1286,1396)$. This wreath is referred to several times during Tschionatulander's quest to earn her love (1324f., 1411, $1427 \mathrm{f}$., 1707). The inscriptions declare it as Sigune's gift and a symbol of her virginity, and connect it to his lance, which Sigune adorned with another band inscribed with her promise that if he succeeds she will exchange the wreath with a wife's headband, anticipating the lovers' union on a symbolic level (1243-1249). ${ }^{58}$ Still, when they reunite, Sigune sends Tschionatulander off again, appealing to her conditions as written on the wreath, and pointing out that the letters are still lacking battle traces, as if it was a legal contract to be signed with the material marks of the feats performed for her (1946-1947).

Connected to the motif of inscribed hearts in religious literature, engraved jewellery can also occur as an image for lovers' intimate inseparability and sincerity. In

graved with Pensez de moy $(1854,1130.48)$, or the Finger-ring with a grammatical love riddle (British Museum AF.1077). See also Scarisbrick 1993, 19.

53 See Smith 1908, 152-153; Graf 2011, 688f.

54 See Smith 1908, 37f.

55 See Jüdischer Hochzeitsring, Alte Synagoge Erfurt 5067/98; Bague de mariage du trésor de Colmar, Musée de Cluny Cl. 20658; See also Scholz 2013, 189f; Krabath 2016, 248f.

56 See Smith 1908, 261-262. In William Shakespeare's The Merchant of Venice, Nerissa's ring is inscribed "Love me and leave me not" (5.I.147-253). Shakespeare's Hamlet calls the acting troop's prologue short as "the posy of a ring” (3.II.133).

57 See Diu Crône, 23242-23434; Maxims I (B), 11f.; Boccaccio 1992, III.8, 9, IV.6, X.8; Wittenwiler 2012, 5277-5287.

58 See Trînca 2010, 199-202. 
Wilhelm von Österreich (1314), the narrator mentions that Love has entwined Wilhelm's heart with his lady's like molten gold and sapphires, while she bears Wilhelm's name engraved into her golden heart, evoking the image that inscriptions in the materials of jewellery resist change and entangle different precious elements (12763-12780). ${ }^{59}$

In Chaucer's Troilus and Criseyde (c. 1380), too, the couple talks of engraving each other indelibly into their hearts to express faithfulness (3.1485-1505). But this imagery changes when appearing in combination with the inaccessibility of the heart's secrets. When Troilus and Criseyde exchange rings-the most secretive form of jewellery given by lovers-the narrator claims he cannot say anything about the inscriptions, thus constructing a sphere of intimacy between the lovers that excludes even him: [they] pleyinge entrechaungeden hire rynges / of whiche I kan nought tellen no scripture (3.1368-1369). This tension between objects, verbal explanations, and the truth about the characters' actions and intentions intensifies in a later constellation. After the couple's separation, Troilus is left in agony about Criseyde's plans to return to him, until he discovers a brooch he once gave her on Diomedes's sleeve and realises she has a new lover (5.1037-1043, 5.1655-1666, 5.1688-1698). But the brooch does not reveal how and why Criseyde actually broke her vows to Troilus. The intimacy of rings inscribed with undisclosed secrets of faithfulness falls apart into silent, seemingly self-explanatory material objects on one side, verbal dream interpretations, letters and promises on the other, while the characters' true motives turn into blank spaces that cannot be read or known anymore. ${ }^{60}$

Similar scenes of lovers giving jewellery as farewell gifts appear often in courtly literature. Such items reflect the lovers' faithfulness and witness their vows of loyalty. ${ }^{61}$ In the Norwegian Tristrams saga (c. 1250), Tristram inscribes the ring Isolde gave him at his departure with her words of farewell and puts it on the hand of her lifelike sculpture. ${ }^{62}$ This moves beyond memorial purposes: When Tristram kisses and talks to Isolde's statue, he returns to the moment the ring's inscription encapsulates.

Losing jewellery linked to constancy usually bodes ill. ${ }^{63}$ However, occasionally, it is passed on to authorise a messenger, as in the Stanzaic Guy of Warwick (388-393, 3433-3441, 3457-3474). Lovers also often use jewellery to identify themselves, in the face of challenges like a long absence or need for secrecy. ${ }^{64}$ In the Middle English

59 See also Ariosto 2016, XLIV,65-66; Gower 1901, I.550-556.

60 See Patterson 1991, 138-155; Johnston 2010, 254-259.

61 For example, see Johann von Würzburg 1970, 2898-3036.

62 Tristan-Stoff in Skandinavien 2008, 104-106, see also 110-112; see also Thomas d'Angleterre 1985, “Turin Fragment I", 941-990, “Cambridge Fragment” 49-52; Gottfried von Straßburg 2016, 1831118367, Beroul 1998, 2707-2730, 2792-2802.

63 See, for example, Ariosto 2016, XIX,37-40, XXIII,100-121; Thomas d’Angleterre 1985, "Sneyd Fragment", 443-462; Tristan-Stoff in Skandinavien 2008, $94 \mathrm{f}$.

64 See, for example, Deux Poémes de la Folie de Tristan, 943-975 (Oxford MS); Kudrun, 1247-1250; Boccaccio 1992, X.9, III.7. On recognition in medieval literature, see Schulz 2008, 8-24, 37, 331-354, 498-505. 
King Horn (late thirteenth century), Horn, an exiled prince, shows his lover princess Rymhild her parting present-a ring bearing her name in one MS, with the addition of "loves you" in two other MSS-when he returns in disguise in order to test her reaction to false news of his death before revealing himself (25f., 52-55). This is a trial of faithfulness, but Horn also puts himself, and the future of their secret engagement, into Rymhild's hands by returning the ring that symbolises their love and grants him magical invincibility $(28,68) .{ }^{65}$ In contrast to such a fidelity test, in König Rother (c.1160-1170), Rother, hidden among his enemies, slips a ring inscribed with his name into his wife's hand, not so much to reveal his identity, but to let her know he is present (3874-3914).

Such items often raise the question of how someone got hold of them-were they stolen, taken from the dead lover, entrusted to a messenger, or given away freely? Misunderstandings can have fatal consequences. ${ }^{66}$ However, inscriptions do not seem to protect jewellery from such ambiguities; on the contrary, they sometimes even serve to deliberately create them. In some redactions of the short tale Der Schüler von Paris (thirteenth/early fourteenth century), a girl fabricates a story of an affair with a student in confession and sends the confessor to return an ornament she allegedly received from her lover. In actuality, it is all a trick to initiate the affair in the first place, to send the student a gift, and to inform him about her cunning plan for their first secret rendezvous. ${ }^{67}$ The student in turn has a brooch crafted for her, which he asks the confessor to return: it contains an emblem of a maid shooting an arrow through a man's heart which, in redaction B of the "Gesamtfassung G", is encircled with the verses,

\author{
Ach reine süeze Minne, \\ Du gibest verborgene sinne \\ Mangem kranken herzen, \\ Daz von der liebe smerzen \\ Im erdenket solichen funt, \\ Der im sus selden würde kunt \\ Und iemer mê wær tiure \\ âne dîner helfe stiure. \\ (466-474)
}

\author{
Oh pure, sweet love, \\ you grant hidden senses \\ to many an ill heart \\ so that because of love's pains \\ it can conceive such ideas \\ it otherwise hardly could learn of \\ and would be at loss for \\ without your help's guidance. ${ }^{68}$
}

65 Cf. Gower 1901, IV.645-671, and Oesterley 1872, 287f., for engraved rings erasing lovers' memories. 66 Cf. Starobinski 2007. See, for example, Wolfram von Eschenbach 2012, 127.25-128.2, 130.26-137.30, 269.18-270.11; Nibelungenlied, 676-677, 844-851.

67 The popular motif of the ignorant messenger often involves jewellery as gifts (Boccaccio 1992, III.3), which sometimes also bear inscriptions. See, for example, the inscribed ring in Der Mönch als Liebesbote B, 203-208, 316-335, and compare to Der Mönch als Liebesbote A, 81-197, which treats the plot differently and only mentions an exchange of uninscribed rings. See also Grubmüller's commentary in the same edition, 1197-1201, and Rosenfeld's commentary on Der Schüler von Paris, 499-522. 68 Compare also to redaction A of Der Schüler von Paris, printed on the same pages, that omits the inscription. 
Here we see that, despite its locomobility, ${ }^{69}$ inscribed jewellery heavily relies on situational ties (especially to the relationships of the people involved). The fabricated background story turns the brooch into a gift sent back to symbolically end a relationship, using a rather commonplace inscription; but read within the true situation it appears as a counter-gift initiating a relationship, communicating that the student has understood the girl's ruse, and was only able to do so because he returns her love. Therefore, the situational ties of inscribed jewellery are not mere restrictions-they can creatively construct ambiguity and polyvalence, instead of exorcising it. In this instance, this effect allows lovers to communicate secrets hidden in plain sight.

Of course, love in medieval literature must not be confused with modern, romantic conceptions of love. Divisions between community and individual, private and public, are fundamentally different in the Middle Ages, something that the logic of gift exchange in love narratives can demonstrate. In dynastic marriages, jewellery can be an amatory, as well as a political marker. A wedding and coronation can be seen as the exchange of a ring for a crown that publicly re-defines the couple's relationship and political positions. The service of love and declarations of power converge in particularly interesting ways in inscribed crowns on helmets. The medieval German hero Lohengrin wears a helmet topped off with a crown whose gemstone letters declare he is fighting for the duchess of Brabant. ${ }^{70}$ This introduces the stranger under a familiar name and defines his campaign as a service of love to his wife.

Thus, inscribed jewellery allows literature to entangle different spheres, such as politics, social standing, and love, and shows that in medieval literature some of these fields are hardly separable in the first place. However, there is yet another field central to such constellations of inscribed jewellery both on the level of material objects and practices as well as on the level of poetical language and rhetoric-that of religion.

\subsection{Religion}

Medieval jewellery was often decorated with religious motifs, like crosses, and could be part of religious practices, such as rosary prayers. Cult objects could be worn as pendants, or be adorned with jewellery. ${ }^{71}$ Jewellery with spiritual inscriptions expressing the relationship between God and believer occur frequently, such as nomen ehlla fid in xpo ("my name is Ella; my faith is in Christ"), naine mi xps ("negate me Christ”), or simply AVE MARIA. ${ }^{72}$

69 See Ehlich 1994, 30.

70 See the thirteenth-century romance Lohengrin, 5311-5350.

71 See Evans 1976, 133-136.

72 For an overview, see, for example, Evans 1976, 121-139. For the individual examples, see Finger-ring, (Ashmolean Museum AN1970.1067), described in Okasha 2003, 35; for analysis of the Paußnitz ring, 
Inscriptions can also express communication with God. For instance, the visions of the mystic Gertrude of Helfta (twelfth/early thirteenth century) describe how in Heaven, whenever a believer prays to a saint, a corresponding gem Christ is wearing casts a beam of light inscribed with the believer's name on the saint. ${ }^{73}$ However, since this article focusses on secular literature and leaves aside the vast body of religious texts, I will discuss the spiritual significance of inscribed jewellery in constellations interweaving social, political or amatory relationships.

Some Biblical verses connect adornment to vain worldliness (such as 1. Peter 3:36). But in others receiving (Ezekiel 16:11-39) or losing jewellery (Isaiah 3:16-23) occurs as a spiritual image for enjoying God's favour, which, in turn, is often expressed in the metaphor of being God's child or bride. Similar images occur in literary texts such as Pearl (late fourteenth century), Die Hochzeit (c. 1160), or the Barlaam and Josaphat material. ${ }^{74}$ Jewellery inscriptions elaborating on the relationship between God and a believer mirror a range of human relationships. The Gesta Romanorum exempla mentioned above all relate jewellery given and taken by people to spiritual salvation. For example, the commentary on chapter 1 identifies the different characters presenting the princess with inscribed jewellery as figures for Christ. An eleventh-century Anglo-Scandinavian brooch explores instead the different ways jewellery can shape relationships: It bears the inscription " $Æ d w e n$ owns me, may the Lord own her. May the Lord curse him who takes me from her, unless she gives me of her own free will” on its back. ${ }^{75}$ The inscription, comparing Ædwen's relation to the personified brooch with her relationship to God, anticipates different ways of owning the brooch. ${ }^{76}$

Such images of jewellery-giving can also rely on political paradigms. Ascension, found in the Old English Exeter Book (probably tenth century) calls Christ the apostles' treasure-giver, and ring-giving appears as an image for spiritual allegiance. ${ }^{77}$ The Exeter Book also contains two of the rare references to inscribed rings in Old English literature, which even draw on gift-circulation to describe a religious community. In "Riddle 48", a golden hring ("ring”) silently declares "Heal me, helper of souls" to

see Muhl 2003; also mentioned in Krabath 2016, 254; ‘Eawen’ ring (British Museum AF.459), discussed in Okasha 2003, 30f., 35f.

73 See Trînca 2016, 356-359, 353f.

74 See Pearl, 217-240, 277-360, 729-780; Die Hochzeit, 19,5f., 28,8-10, 23,2-4, 47-52; Rudolph von Ems 1965, 1466-1584, 3125-3176, compare also to Matthew 13:44-46; for an overview on luxury in the Barlaam and Josaphat material, see Traulsen 2015.

75 AEDVPEN ME AG AGE HYO DRIHTEN / DRIHTEN HINE APERIE ĐE ME HIRE AETFERIE / BVTON HYO ME SELLE HIRE AGENES PILLES; see Aedwen Brooch (British Museum 1951,1011.1); See also Thornbury 2001.

76 See Ramey 2013, 341-343.

77 See Ascension, 19-21; on spiritual ring-giving resembling political or amatory ring-exchange, see Deutsche Kaiserchronik, 13067-13376; Boccaccio 1992, I.3; Song 42 of the Cantigas de Santa Maria, 160-163, see also http://csm.mml.ox.ac.uk/index.php?p=poemdata_view\&rec=42 (last accessed: 30.05.2019). 
those who should put their faith in God (320). In "Riddle 59", a golden hring silently names its Lord so that people who understand will be saved, emphasising that many people are handling the ring (326f.). Often, both riddles are solved as referring to inscribed cult objects, usually chalices, communion patens, or bells. However, rings have also been suggested as a possible solution. ${ }^{78}$ Hring and beag also mean "bracelet”, “collar”, “crown”, "circle”, and could also be metaphors. ${ }^{79}$ Nonetheless, independent of their solutions, "Riddle 48" and "Riddle 59" show that rings, when passed on, could weave relationships not just between people, but also between people and God. The first-person inscription in "Riddle 48" can be understood as the ring itself speaking the words constituting this community. The inscription materialises a shared prayer. 80 "Riddle 59" rather connects the ring to God. A pun on ben ("wound") and bén ("prayer") might connect the Lord's wounds, which the ring might depict, to the letters carved into the ring's body as speaking wounds. ${ }^{81}$ If the hrings can save souls, they are powerful actants working on God's behalf.

Similar metaphors of jewellery-giving can create another effect in connection to Mary as a noble lady or the Queen of Heaven. In the song Mein trost, Maria, raine mait (second half of fourteenth century), the poet imagines himself giving Mary a ring beset with the gemstone letters JHESVS, each interpreted individually. ${ }^{82}$ The ring represents the year's circle and the lay itself, given as a gift to the Queen of Heaven; the letters' gemstone allegories connect to Christ's life. Such examples can also intensify the connection between devotion and love. Die Goldene Schmiede (c. 1280), for instance, describes the angelic salutation âvê as God's wedding ring to Mary (humanity) engraved with the Trinity's image (1892-1915), thus connecting genealogical, amatory, political and religious commitment to the words of one of the most important prayers in spiritual practices.

Such combinations of hierarchical position with religious virtue are common in medieval poetic language, often occurring in amatory contexts (love being one of the highest courtly pursuits), and frequently using jewellery as an image for moral excellence. ${ }^{83}$ Such items can bear moral or religious teachings. ${ }^{84}$ On a rhetorical level, “crown” and "wreath" both occur as metonymies for excellence, especially

78 See Okasha 1993, 62-67. There is evidence of inscribed Insular chalices, such as the Tassilo Chalice kept at Kremsmünster Abbey, Austria. See Webster 1991, 168. For a connection between the concepts of materiality articulated in first-person inscriptions on Anglo-Saxon rings and the Exeter Riddles, see Tiffany 2001, 72-74; Dale 2017, 66f.; Ramey 2013, 344-346.

79 “hring” and “béah", in: Bosworth-Toller 2010, http://www.bosworthtoller.com/019780 and http:// www.bosworthtoller.com/003091 (last accessed: 22.01.2019). See also Okasha 1993, 63f.

80 For a discussion of "paten" as a solution that shows the connections between medical, magical and liturgical practices, see Cavell 2017, 133-137.

81 See, for example, the Coventry Ring (British Museum AF.897).

82 See Der Mönch von Salzburg 1972, G11, 179-184.

83 See, for example, Wigalois, 9737-9739, 10219f.; Wolfram von Eschenbach 2012, 3,11-19.

84 See the complex brooch in Johann von Würzburg 1970, 12842-12873. 
concerning virtues, which makes sense if aristocracy is connected to moral superiority. ${ }^{85}$ This can occur in combination with allegorical interpretations of the items' materials. In Konrad von Würzburg's Die Klage der Kunst (thirteenth century), the names of personified virtues appear on their crowns (stanza 6-12). Der Ring satirises such images in a made-up vision of Venus wearing a glass crown engraved with her name, along with the Virgin, who wears three interlaced crowns made of iron (inscribed as the crown of steadfastness), silver (chastity) and gold (salvation) (2286-2476). In Wilhelm von Österreich, two crowns topping off the hero's helmet even materially act out the connection between love, virtue, faith, and power: Wilhelm's first crown's gemstone letters spelling “CUPIDO” detach if its wearer lacks the virtues the stones represent (3899-3984, 4044-4129, 13874-14013). Hence, only a morally flawless knight can be crowned a servant of love. But the crowned helmet Wilhelm wins later supersedes this: Its gemstone letters form an extensive teaching about putting the service of God above everything else (13874-14013).

Some of the most complex examples of inscribed jewellery entwine religious, political, and amatory relationships in such ways. In addition to Chaucer's Prioress's brooch (discussed in the British Literature chapter) we also see this at the conclusion of Gower's Confessio Amantis (c. 1390). Venus gives a black rosary covered with the golden words Por reposer to Amans when absolving him, so that he might pray for peace and write his book (VIII.2902-2970). This rosary in particular blends together the relationships between a servant and a queen, a lover and his lady, a penitent and his confessor, a believer and God, and a poet and his muse. The inscription then dedicates this charged gift to a specific purpose: The act of recovery and penance that brings all of these spheres together is the act of writing the Confessio Amantis; that is, writing poetry about love is a service and rosary prayer to love itself.

\section{Conclusion}

In medieval literature, jewellery, understood as precious ornaments worn on the body, exceeds its aesthetical function. As a mark of distinction, jewellery can express hierarchy and social position. As a gift, it can create political power. It can also symbolise the direct relationship between two people, such as a lord and a servant or two lovers. Such constellations can produce narrative tension depending on how openly the relationship is connected to the community-as a wreath publicly worn, or a ring secretly given. Because jewellery is almost always concerned with relationships, it is crucial for an inscription's interpretation to ask which character gave what kind of item, with which history and obligations attached to it, to whom, under what circumstances, and how publicly. Inscriptions here do not serve as simple name tags-they

85 See Wigalois, 8884-8887. 
can intensify and personalise gifts, pass on a giver's authority, or add new levels and ambiguities. On a synchronic level, one object can express different meaning to different characters, and can diachronically change its function, just as an inscription's significance is related to situational and material aspects. Characters can use this to send messages hidden in plain sight. Inscribed jewellery that entwines different spheres is particularly interesting-for example when a poet imagines giving his poem as a ring of love to the Queen of Heaven.

This article focussed on how inscribed jewellery entangles political, social, amatory and spiritual functions. I hope to encourage more research on aspects I could only mention here, such as the way inscribed jewellery can create and work with power, or a perspective on gender and power. ${ }^{86}$ Questions of media, intermediality, and Schriftbildlichkeit ("notational iconicity"), promise further insights into the relation between engraved images and inscriptions. ${ }^{87} \mathrm{~A}$ complex corpus invites research on the role of jewellery in spiritual literature. Approaches informed by intertextual or material culture studies would illuminate the connections between jewellery and other material objects such as weapons or architecture. Actor Network Theory especially promises to be useful for understanding the agency of jewellery. ${ }^{88}$

Another, last field would be the relation between jewellery appearing as material items in narration to jewellery in figures of speech, and the relations between jewellery and poetry in general. Some connections can be concretely material-as with the famous Alfred Jewel, a gold-and-enamel-wrought crystal inscribed AELFRED MEC HEHT GEWYRCAN ("Alfred had me made") probably used as a text pointer. ${ }^{89}$ In the early fifteenth century, diamond rings were used to carve inscriptions upon glass. ${ }^{90}$ Manuscripts also could be decorated like jewellery. ${ }^{91}$ Jewellery frequently appears in texts as a reward for poets. ${ }^{92}$ But the connection can also lie on the level of literary language. Wisdom and God's word can be described with images of jewellery. ${ }^{93} \mathrm{Sim}$ ilar imagery also occurs for the value of literature itself, often in prologues or epilogues because of their metapoetical potential. ${ }^{94}$ Diu Crône's epilogue calls the text a crown for worthy people, the Ring's prologue (probably 1408/1410) compares itself to a ring teaching wisdom about the world, while the poet of Die goldene Schmiede wishes he could melt gold in his heart and craft a jewelled poem to praise the Virgin,

\footnotetext{
86 On power, see, for example, Foucault 1982; see also Walker-Bynum 2011, $274 \mathrm{f}$.

87 See Krämer/Cancik-Kirschbaum/Totzke 2012; Krämer 2014.

88 See, for example, Latour 2005, 79-86.

89 See the Alfred Jewel (Ashmolean Museum, AN1836.p135.371).

90 See Fleming 2001, 55; Smith 1908, 260.
}

91 See, for example, “Riddle 26”, Exeter Anthology 2000, 303f; see Bitterli 2009, 176f.; Holsinger 2009, $621 \mathrm{f}$.

92 See, for example, Kudrun, 398; Widsith, 65-102.

93 See Solomon and Saturn, 63-65; Maxims II, 10-13.

94 See Die Hochzeit, 1-7; Diu Crône, 11-27, 49-71, 89-139; compare Wigalois, 75-89 to Matthew 7:6; Johann von Würzburg 1970, 20-123. 
honouring Gottfried von Straßburg as a master-smith of golden poems. ${ }^{95}$ Some descriptions of jewellery even reflect upon the fact they are poetic creations made of words, not metal. ${ }^{96}$ Such moments of explicit literary self-reflexivity set up material reality against literary constructs of material objects only to then intricately entwine them.

\section{Works Cited}

\section{Primary Sources}

Albrecht von Scharfenberg (1955), Jüngerer Titurel, vol.1, ed. by Kurt Nyholm, Berlin.

Ariosto, Ludovico (2016), Orlando furioso, ed. by Emilio Bigi, Cristina Zampese and Piero Floriani, Milan.

The Ascension (2000²), in: The Exeter Anthology of Old English Poetry, ed. by Bernard J. Muir, Exeter, 63-78.

Béroul, Tristan (1998), in: Early French Tristan poems, vol.1, ed. by Norris J. Lacy, Cambridge, 3-216. Boccaccio, Giovanni (1992), Decameron, ed. by Vittore Branca, Turin.

Cantigas de Santa María I, de Alfonso X, o sábio, vol.1: Cantigas 1 a 100 (1986), ed. by Walter Mettmann, Madrid.

Chaucer, Geoffrey (2006), Troilus and Criseyde, with Facing-page Il Filostrato, ed. by Stephen A.

Barney, New York.

Deutsche Kaiserchronik (1964), ed. by Edward Schröder, unaltered edition from 1895, Berolini 1964. Les Deux Poèmes de la Folie de Tristan (1965, reprint 1907), ed. by Joseph Bédier, New York.

The Exeter Anthology of Old English Poetry $\left(2000^{2}\right)$, ed. by Bernard J. Muir, Exeter.

Gesta Romanorum (1872), ed. by Hermann Oesterley, Berlin.

Gottfried von Straßburg (2016), Tristan, ed. by Karl Marold and Werner Schröder, Berlin.

Gower, John (1901), Confessio Amantis, in: The complete works of John Gower, vol. 2 and 3, ed. by

G. C. Macaulay, Oxford.

Der Große Alexander aus der Wernigeroder Handschrift (1908), ed. by Gustav Guth (Deutsche Texte des Mittelalters, 13), Berlin.

Heinrich von dem Türlin (2012), Diu Crône, ed. by Gudrun Felder, Berlin.

Heinrich von Veldeke (1997), Eneasroman, ed. and introd. by Dieter Kartschoke (RUB 8303), Stuttgart.

Die Hochzeit (2016); in: Die religiösen Dichtungen des 11. und 12. Jahrhunderts, vol. 2, ed. by Friedrich Maurer, Tübingen, 179-223.

Johann von Würzburg (1970), Wilhelm von Österreich. Aus der Gothaer Handschrift, ed. by Ernst Regel, Dublin.

Kaufringer, Heinrich (1972), Der Mönch als Liebesbote B, in: Werke, ed. by Paul Sappler, Tübingen, 81-91.

King Horn (1962), in: King Horn, Floriz and Blauncheflur, The Assumption of Our Lady, ed. by George H. McKnigh (Early English Text Society OS 14), London, 1-69.

95 See Wittenwiler 2012, 29915-30000; Der Ring, 1-14; Konrad von Würzburg 1840, 1-9, 34-43, 94-99. 96 See Wigalois, 10556-10576, 769-791. 
Klaeber's "Beowulf", and "The Fight at Finnsburg" (2009), ed., with introduction, commentary appendices, glossary, and bibliography by R. D. Fulk, Toronto.

König Rother (2000), ed. by Ingrid Bennewitz, trans. by Peter K. Stein, Stuttgart.

Konrad von Würzburg (1840), Die Goldene Schmiede, ed. by Wilhelm Grimm, Berlin.

Konrad von Würzburg (1959), Die Klage der Kunst, in: Kleinere Dichtungen Konrads von Würzburg, vol. 3, ed. by Edward Schröder, Berlin, 1-8.

Kudrun (2000), ed. by Karl Stackmann following Karl Bartsch, Tübingen.

Liederbuch der Clara Hätzlerin (1840), ed. by Carl Haltaus, Quendlinburg.

Lohengrin. Edition und Untersuchung (1971), ed. by Thomas Cramer, Munich.

Maxims I (B) $\left(2000^{2}\right)$, in: The Exeter Anthology of Old English Poetry, ed. by Bernard J. Muir, Exeter, 252-254.

Maxims II (1958), in: The Anglo-Saxon Minor Poems, ed. by Elliott van Kirk Dobbie, London, 55-57.

Der mittelalterliche Tristan-Stoff in Skandinavien (2008), ed., introd., trans. and with a bibliography by Heiko Uecker, Berlin.

Der Mönch als Liebesbote A (1996), in: Novellistik des Mittellalters, ed. by Klaus Grubmüller, Frankfurt am Main, 524-543.

Der Mönch von Salzburg (1972), Die geistlichen Lieder des Mönchs von Salzburg, ed. by Franz Viktor Spechtler.

Das Nibelungenlied (2017), ed. by Hermann Reichert, Berlin.

The Passion of Saint Juliana (2000²), in: The Exeter Anthology of Old English Poetry, ed. by Bernard J. Muir, Exeter, 188-214.

Pearl (1996), in: The Poems of the Pearl Manuscript, ed. by Malcolm Andrew/Ronald Waldron, 53-110.

Publius Vergilius Maro (2008), Aeneis, Lateinisch/Deutsch, ed. and trans. by Edith and Gerhard Binder, Stuttgart.

Le roman d'Eneas (1972), trans. by Monica Schöler-Beinhauer, Munich.

Rudolf von Ems (1965), Barlaam und Josaphat, ed. by Franz Pfeiffer (Texte des Mittelalters), Berlin.

Der Schüler von Paris B, in: Novellenstudien. 1. Der Hellerwertwitz, 2. Der Schüler von Paris (1927), ed. by Hans-Friedrich Rosenfeld, Leipzig, 394-449.

The Seafarer (2000²), in: The Exeter Anthology of Old English Poetry, ed. by Bernard J. Muir, Exeter, 229-233.

Seifrit (1932), Alexander, aus der Straßburger Handschrift, ed. by Paul Gereke (Deutsche Texte des Mittelalters 36), Berlin.

Solomon and Saturn (1958), in: The Anglo-Saxon Minor Poems, ed. by Elliott van Kirk Dobbie, London, 31-48.

The Stanzaic Guy of Warwick (2004), ed. by Alison Wiggins (Middle English Text Series), Kalamazoo, MI.

Thomas d'Angleterre (1985), Tristan, ed. and trans. by Gesa Bonath (Klassische Texte des Romanischen Mittelalters in zweisprachigen Ausgaben 21), Munich.

The Wanderer (2000), in: The Exeter Anthology of Old English Poetry, 215-219.

Widsith (2000), in: The Exeter Anthology of Old English Poetry, 238-243.

Wirnt von Grafenberg (2014), Wigalois, trans. and introd. by Sabine Seelbach and Ulrich Seelbach, ed. by J. M. N. Kapteyn, Berlin.

Wittenwiler, Heinrich (2012), Der Ring. Nach der Münchener HS, mit Abdr. des Textes nach Edmund Wießner, ed. and trans. by Werner Röcke, Berlin.

Wolfram von Eschenbach (2012), Parzival. Studienausgabe, ed. by Bernd Schirok after Karl Lachmann, trans. by Peter Knecht, Berlin. 


\section{Secondary Sources}

Backhouse, Janet/Webster, Leslie (1991), The Making of England. Anglo-Saxon Art and Culture; AD 600-900 (Exhibition Catalogue of the British Museum, 18. November 1991-13. March 1993), London.

Bammesberger, Alfred (2003), “The Harford Farm Brooch Runic Inscription”, in: Neophilologus 87 (1), 133-135.

Bintley, Michael, $\left(2012^{2}\right)$, "Material Culture. Archaeology and Text”, in: Richard North and Joe Allard (eds.), Beowulf and Other Stories. A New Introduction to Old English, Old Icelandic and Anglo-Norman Literatures. Harlow, 246-273.

Bitterli, Dieter (2009), Say What I am Called. The Old English Riddles of the Exeter Book and the Anglo-Latin Riddle Tradition, Toronto.

Bode, Christoph (1994), “'Look on my Works, ye Mighty, and despair!' Notes on the Non-Teachability of Poetry”, in: Anglistik \& Englischunterricht 53, 139-152.

Bosworth, Joseph, An Anglo-Saxon Dictionary Online (2010), ed. by Thomas Northcote Toller, comp. by Sean Christ and Ondřej Tichý, Prague, <http://www.bosworthtoller.com> (last accessed: 22.01.2019).

Brepohl, Erhard (1999²), Theophilus Presbyter und das mittelalterliche Kunsthandwerk, 2 vols., Cologne.

Bynum, Catherine Walker (2011), Christian Materiality. An Essay on Religion in Late Medieval Europe, Brooklyn.

Cavell, Megan (2017), "Powerful Patens in the Anglo-Saxon Medical Tradition and Exeter Book Riddle 48", in: Neophilologus 101 (1), 129-138.

Cohen, Jeffrey Jerome (2015), Stone. An Ecology of the Inhuman, Minneapolis.

Dale, Corinne (2017), The Natural World in the Exeter Book Riddles, Cambridge.

Dalton, Ormonde Maddock (1912), Franks Bequest Catalogue of the Finger Rings, Early Christian, Byzantine, Teutonic, Mediaeval and Later, London.

Eger, Christoph (2004), "Krone und Kreuz König Svinthilas. Westgotische Hofkunst und Plate-inlaying im 6. und 7. Jh.", in: Madrider Mitteilungen 45, 449-506.

Ehlich, Konrad, "Funktion und Struktur schriftlicher Kommunikation”, in: Hartmut Günther and Otto Ludwig (eds.), Schrift und Schriftlichkeit/Writing and Its Use. Ein interdisziplinäres Handbuch internationaler Forschung/An Interdisciplinary Handbook of International Research (Handbuch zur Sprach- und Kommunikationswissenschaft 10.1), Berlin, 18-41.

Egidi, Margreth/Lieb, Ludger/Schnyder, Mireille/Wedell, Moritz (eds.) (2012), Liebesgaben. Kommunikative, performative und poetologische Dimensionen in der Literatur des Mittelalters und der Frühen Neuzeit (Philologische Studien und Quellen 240), Berlin.

Eming, Jutta/Pailer, Gaby/Schößler, Franziska/Traulsen, Johannes (2015), “Einleitung”, in: Jutta Eming, Gaby Pailer, Franziska Schößler and Johannes Traulsen (eds.), Fremde - Luxus - Räume. Konzeptionen von Luxus in Vormoderne und Moderne, Berlin, 7-17.

Engle, David G. (1981): “Edelstein”, in: Enzyklopädie des Märchens 3, 1003-1009.

Evans, Joan (1931), English Posies and Posy Rings, London.

Evans, Joan (1976), Magical Jewels of the Middle Ages and the Renaissance, particularly in England. New York.

Fährmann, Sigrid (1996), “Krone”, in: Enzyklopädie des Märchens 8, 491-494.

Felski, Rita (2011), “Context Stinks!”, in: New Literary History 42 (4), 573-591.

Fleming, Juliet (2001), Graffiti and the Writing Arts of Early Modern England, London.

Foucault, Michel (1982), “The Subject and Power”, in: Hubert Dreyfus and Paul Rabinow (eds.), Beyond Structuralism and Hermeneutics, Brighton, 208-226. 
Gaimster, Märit (2011), “Image and Power in the Early Anglo-Saxon Period”, in: Helena Hamerow, David A. Hinton and Sally Crawford (eds.), Oxford Handbook of Anglo-Saxon Archaeology, Oxford, 865-891.

Graf, Klaus (2011), “Ring”, in: Enzyklopädie des Märchens 11, Berlin, 688-696.

Harris, Anne F./Overbey, Karen (2014), “Field Change/Discipline Change”, in: Jeffrey J. Cohen (ed.), Burn After Reading, vol. 2: The Future We Want, New York, 127-143.

Herman, Melissa (2017), "The More Things Change, the More they Stay the Same. Decorative Continuity in Early Anglo-Saxon England", in: Michael J. D. Bintley, Martin Locker, Victoria Symons and Mary Wellesley (eds.), Stasis in the Medieval West? Questioning Change and Continuity (The New Middle Ages 1), New York, 47-68.

Hilgert, Markus (2010), “'Text-Anthropologie'. Die Erforschung von Materialität und Präsenz des Geschriebenen als hermeneutische Strategie", in: Markus Hilgert (ed.), Altorientalistik im 21. Jahrhundert. Selbstverständnis, Herausforderungen, Ziele. (Mitteilungen der Deutschen Orientgesellschaft 142), Berlin, 87-126.

Hinton, D. A. (1975), “Late Anglo-Saxon Metalwork. An Assessment”, Anglo-Saxon England 4, 171-180.

Holsinger, Bruce (2009), "Of Pigs and Parchment. Medieval Studies and the Coming of the Animal", in Proceedings of the Modern Language Association 124 (2), 616-623.

Horn, Katalin (1987), “Gold, Geld”, in: Enzyklopädie des Märchens 5, 1357-1372.

Johnston, Andrew J. (2008), Performing the Middle Ages from 'Beowulf to 'Othello', Turnhout.

Johnston, Andrew J. (2009), “Medialität in Beowulf”, in: Germanisch-Romanische Monatsschrift 59, 129-147.

Johnston, Andrew J. (2010), “Geschlechter-Lektüren. Emotion und Intimität in Chaucers Troilus and Criseyde”, in: Ingrid Kasten (ed.), Machtvolle Gefühle, Berlin, 246-261.

Johnston, Andrew J. (2016), "Schriftkommunikation im Beowulf", in: Friedrich-Emanuel Focken and Michael R. Ott (eds.), Metatexte. Erzählungen von schrifttragenden Artefakten in der alttestamentlichen und mittelalterlichen Literatur (Materiale Textkulturen 15), Berlin/Boston, 205-215.

Johnston, Andrew J. (2017), “Material Studies”, in: Leah Tether and Johnny McFadyen (eds.), Handbook of Arthurian Romance. King Arthur's Court in Medieval European Literature, Berlin, 225-238.

Klingner, Jacob/Lieb, Ludger (2013), Handbuch Minnereden, vol.1, Berlin.

Krabath, Stefan (2016), "Schmuck im Mittelalter. Grundlegende Formen in ihrer Entwicklung vornehmlich aus archäologischer Sicht”, in: Das Mittelalter 21, 246-272.

Krämer, Sybille (2014), “Notational Iconicity. A New Concept in the Humanities”, in: V. Boris Kochan (ed.), Granshan: Design and Identity. The Non-Latin Typeface Project, Munich, 160-165.

Krämer, Sybille/Cancik-Kirschbaum, Eva/Totzke, Rainer (eds.) (2012), Schriftbildlichkeit. Wahrnehmbarkeit, Materialität und Operativität von Notationen, Berlin.

Latour, Bruno (2005), Reassembling the Social. An Introduction to Actor-Network-Theory, Oxford.

Lévi-Strauss, Claude (1969), The Elementary Structures of Kinship, Boston.

Lieb, Ludger (2015), “Spuren materialer Textkulturen. Neun Thesen zur höfischen Textualität im Spiegel textimmanenter Inschriften”, in: Beate Keller, Ludger Lieb and Stephan Müller (eds.), Höfische Textualität. Festschrift für Peter Strohschneider, Heidelberg, 1-20.

López, Gisela (1994), "The Formation of Visigothic Spain”, in The Art of Medieval Spain, AD 500-1200 (Exhibition Catalogue of the Metropolitan Museum of Art in New York, 18. November-13. March 1994), New York, 41-72.

MacLeod, Mindy/Mees, Bernard (2006), Runic Amulets and Magic Objects, Woodbridge. Mauss, Marcel (2002), The Gift. The Form and Reason for Exchange in Archaic Societies, London. McKinnell, John/Simek, Rudolf/Düwel, Klaus (2004), Runes, Magic and Religion. A Sourcebook (Studia medievalia Septentrionalia 10), Vienna. 
Muhl, Arnold (2003), “Der Inschriftenring von Paußnitz, Ldkr. Riesa”, in: Jahresschrift für mitteldeutsche Vorgeschichte 87, 81-139.

Murphy, G. Ronald (2006), Gemstone of Paradise. The Holy Grail in Wolfram's “Parzival”, New York. Okasha, Elisabeth (1971), Hand-List of Anglo-Saxon Non-Runic Inscriptions, Cambridge.

Okasha, Elisabeth (1973), “A Rediscovered Medieval Inscribed Ring”, in: Anglo-Saxon England 2, 167-171.

Okasha, Elisabeth (1993), “Old English hring in Riddles 48 and 59”, in: Medium Aevum 62, 61-69.

Okasha, Elisabeth (1995), “Literacy in Anglo-Saxon England. The Evidence from Inscriptions”, in: Anglo-Saxon Studies in Archaeology and History 8, 69-74.

Okasha, Elisabeth (2003), "Anglo-Saxon Inscribed Rings", in: Leeds Studies in English XXXIV, 29-45.

Ott, Michael R./Focken, Friedrich-Emmanuel (2016), "Metatexte und schrifttragende Artefakte”, in: Friedrich-Emmanuel Focken and Michael R. Ott (eds.), Metatexte. Erzählungen von schrifttragenden Artefakten in der alttestamentlichen und mittelalterlichen Literatur (Materiale Textkulturen 15), Berlin, 1-10.

Ott, Michael R./Pantanella, Flavia (2014), “Geschriebenes erzählen. Erzählte Inschriften in Minnereden aus narrativer, poetologischer und materialer Perspektive”, in: Iulia-Emilia Dorobanţu, Jacob Klingner and Ludger Lieb (eds.), Zwischen Anthropologie und Philologie. Beiträge zur Zukunft der Minneredenforschung, Heidelberg, 329-362.

Owen-Crocker, Gale R. (2011), "Dress and Identity", in: S. Crawford, H. D. Hinton and H. Hamerow (eds.), The Oxford Handbook of Anglo-Saxon Archaeology, Oxford, 91-116.

Page, Raymond I. (1964), “Appendix A. The Inscriptions”, in: David M. Wilson (ed.), Anglo-Saxon Ornamental Metalwork 700-1100 in the British Museum, London, 67-90.

Page, Raymond I. (1999²), An Introduction to English Runes, Woodbridge.

Patterson, Lee (1991), Chaucer and the Subject of History, Madison.

Platz-Horster, Gertrud (2011), "Seals in Transition. Their Change of Function and Value in Late Antiquity", 225-227, in: Chris Entwistle and Noël Adams (eds.), Gems of Heaven. Recent Research on Engraved Gemstones in Late Antiquity, c. AD 200-600, London, 221-228.

Ramey, Peter (2013): "Writing Speaks. Oral Poetics and Writing Technology in the Exeter Book Riddles", in: Philological Quarterly 92 (3), 335-56.

Rieger, Angelica (ed.) (2016), Schmuck im Mittelalter (Das Mittelalter 16/2), Berlin.

Robertson, Kellie (2010), “Medieval Materialism. A Manifesto”, in: Exemplaria 22 (2), 99-120.

Robinson, James (2008), Masterpieces of Medieval Art, London.

Scarisbrick, Diana (1993), Rings. Symbols of Power, Wealth and Affection, London.

Scholz, Anke K. (2013), “Pest - Pogrome - Pfandleiherhorte. Ein standardisiertes Deutungsschema für spätmittelalterliche Schatzfunde”, in: Mitteilungen der Deutschen Gesellschaft für Archäologie des Mittelalters und der Neuzeit 25, 189-202.

Schulz, Armin (2008), Schwieriges Erkennen. Personenidentifizierung in der mittelhochdeutschen Epik (MTU 135), Tübingen.

Smith, Harold Clifford (1908), Jewellery, New York.

Speer, Andreas (2014), “Zwischen Kunsthandwerk und Kunst. Die 'Schedula diversarum artium' als 'Handbuch' mittelalterlicher Kunst?”, in: Andreas Speer, Maxime Mauriège and Hiltrud Westermann-Angerhausen (eds.), Zwischen Kunsthandwerk und Kunst. Die 'Schedula diversarum artium', Köln, xi-xxxiii.

Starobinski, Jean (2007), Largesse, Paris.

Thornbury, E. V. (2001), “The Genre of the Sutton Brooch Verses”, in: Notes and Queries 48 (4), 375-377.

Tiffany, Daniel (2001); “Lyric Substance. On Riddles, Materialism, and Poetic Obscurity”, in: Critical Inquiry 28 (1), 72-98. 
Traulsen, Johannes (2015), “Diesseitige und jenseitige rîchheit in Rudolfs von Ems' Barlaam und Josaphat”, in: Jutta Eming, Gaby Pailer, Franziska Schößler and Johannes Traulsen (eds.), Fremde - Luxus - Räume. Konzeptionen von Luxus in Vormoderne und Moderne, Berlin, 43-62.

Trînca, Beatrice (2010), “Albrecht's Jüngerer Titurel. A 13th Century Precursor of the Impresa?”, in: Emblematica 18, 195-205.

Trînca, Beatrice (2016), “Schriftliche Berührung - gedruckte Süße. Zum bot der gotlichen mildigkeit", in: Zeitschrift für deutsche Philologie 3, 349-366.

Ward, Anne/Cherry, John/Gere, Charlotte/Cartlidge, Barbara (1981), The Ring from Antiquity to the Twentieth Century, London.

Wärmländer, Sebastian K. T. S./Wählander, Linda/Saage, Ragnar/Rezakhani, Khodadad/Hassan, Saied A. Hamid/Neiß, Michael (2015), "Analysis and Interpretation of a Unique Arabic Finger Ring from the Viking Age Town of Birka, Sweden”, in: Scanning 37, 131-137.

\section{Objects}

Aedwen Brooch, British Museum 1951,1011.1, <https://britishmuseum.org/research/collection_ online/collection_object_details.aspx?objectld=64612\&partld=1\&searchText=1951,1011.1\& page $=1>$ (last accessed: 30.05 .2019 ).

Alfred Jewel, Ashmolean Museum AN1836.p135.371, <http://collections.ashmolean.org/collection/ search/per_page/100/offset/0/sort_by/relevance/object/75670> (last accessed: 30.05.2019).

Athelswith Ring, British Museum AF.458, <https://www.britishmuseum.org/research/collection_ online/collection_object_details.aspx?objectld=91379\&partld=1\&place=29275\&plaA= 29275-3-1\&page $=1>$ (last accessed: 30.05.2019).

Æthelwulf Ring, British Museum 1829,1114.1, <https://www.britishmuseum.org/research/collection_ online/collection_object_details.aspx?objectld=88977\&partld=1> (last accessed: 30.05 .2019 ).

Bague de mariage du trésor de Colmar, Musée de Cluny Cl. 20658, <https://www.musee-moyenage. $\mathrm{fr} /$ collection/oeuvre/bague-mariage-tresor-de-colmar.html> (last accessed: 30.05.2019).

Coventry Ring, British Museum AF.897, <https://britishmuseum.org/research/collection_online/ collection_object_details.aspx?objectld=45589\&partld=1> (last accessed: 30.05 .2019 ).

'Eawen' Ring, British Museum AF.459, <https://www.britishmuseum.org/research/collection_online/ collection_object_details.aspx?objectld=91360\&partld=1\&searchText=AF.459\&page $=1>$ (last accessed: 30.05.2019).

Finger-ring, British Museum 1854,1130.48, <https://britishmuseum.org/research/collection_online/ collection_object_details.aspx?objectld $=51003 \&$ partld $=1 \&$ searchText=inscription \&place $=$ 41618\& from $=$ ad\&fromDate $=300 \&$ to $=$ ad\& toDate $=1500 \&$ object $=22042 \&$ view $=$ list \&page $=2>$ (last accessed: 30.05 .2019$)$.

Finger-ring, British Museum AF.1077, <http://www.britishmuseum.org/research/collection_online/ collection_object_details.aspx?objectld=51115\&partld=1> (last accessed: 30.05 .2019 ).

Finger-ring, British Museum 1995,0902.1, <https://www.britishmuseum.org/research/collection_ online/collection_object_details.aspx?objectld=84852\&partld=1\&searchText=Finger+Ring \& page $=2 \& \&$ sortBy=imageName $>$ (last accessed: 30.05 .2019$)$.

Finger-ring, British Museum OA.10262, <https://www.britishmuseum.org/research/collection_ online/collection_object_details.aspx?objectld=88694\&partld=1> (last accessed: 30.05 .2019 ).

Finger-ring, British Museum SLRings.64, <https://www.britishmuseum.org/research/collection_ online/collection_object_details.aspx?objectld=88816\&partld=1\&searchText=SLRings. 64\&object $=22713 \&$ page $=1>$ (last accessed: 30.05 .2019$)$. 
Finger ring with Latin inscription and male head facing left, Ashmolean Museum AN1970.1067, <http://collections.ashmolean.org/object/312396> (last accessed: 30.05.2019).

Jüdischer Hochzeitsring, Alte Synagoge Erfurt, Erfurter Schatz, 5067/98, <https://thue. museum-digital.de/index.php?t=objekt\&oges $=1530>$ (last accessed: 30.05 .2019 )

Posy Ring, British Museum, AF.1404, <https://britishmuseum.org/research/collection_online/ collection_object_details.aspx?assetld=606554001\& objectld=42586\&partld=1> (last accessed: 30.05 .2019 ). 